\title{
EFFECTS OF GARLIC ON SOME HAEMATOLOGICAL AND BIOCHEMICAL PARAMETERS
}

\author{
F. S. OLUWOLE \\ Department of Physiology, College of Medicine, University of Ibadan, Nigeria.
}

Influence of garlic on some haematological and plasma biochemical parameters were studied in rats that had different doses and duration of garlic pretreatment. 200mg dose of garlic per day for 30 days did not have any significant change $(P>0.05)$ in the red blood cell count and packed cell volume. However at 100mg per day for the same duration, garlic increased red blood cell count and packed cell volume significantly $(P<0.05)$. The same dose $(100 \mathrm{mg})$ of garlic similarly and significantly increased total white blood cell count $(T W B C)$, neutrophil and lymphocyte counts $(P<0.05)$. Garlic thus promote leucopoiesis and increases neutrophil : lymphocyte ratio. Garlic increased sodium and potassium serum levels and may be a good factor in the maintenance of electrolyte balance.

Keywords: Garlic, haematological parameters, electrolytes.

\section{INTRODUCTION}

Garlic commonly known as Allium sativum belongs to the family liliaceace. The plant has many local Nigerian names like ayo in Ibo, ayuu in Yoruba and tafarnuwa in Hausa (Gill, 1992).

Garlic extracts have been used in the treatment of a wide range of disorders in the past (Alan et al, 1995). Sand et al (1995) has also demonstrated that garlic oil is active against fat infiltration of the liver. Allicin, diallyl disulfide-oxide, an active ingredient released from garlic (alliin) is a systemic vasodilator (Sang et al, 1995). Also reported was garlic containing preparation which showed significant decrease in diastolic blood pressure in severely hypertensive patients (McMahon and Vargas, 1993). Ether extracts of garlic and partially purified distilled extracts of garlic have been reported to inhibit human platelet aggregation in vitro (Apitz-Castro et al, 1983). Treatment with garlic extracts was found to improve the activation of natural killer cells, the function of T-lymphocytes and the level of interleukin - 2 (Tang et al, 1997). Also in vitro and in vivo studies showed that aged garlic extracts stimulate immune functions (Sumiyoshi, 1997).

Due to scanty information on the effects of garlic on haematological and biomedical parameters, this study was undertaken to investigate the influence of garlic on certain haematological parameters and plasma electrolyte levels.

\section{MATERIALS AND METHODS}

The Drug: Commercial garlic in tableted form of $900 \mathrm{mg}$ pure garlic per tablet (Golden Neolife Diamate (GND) Int, Pretoria, South Africa) was used. The tablets were dissolved in distilled water according to the required concentrations required for administration to the rats.

Experimental Animals: Male albino rats weighting between 150 and $220 \mathrm{~g}$ were used throughout the investigation. These animals were obtained from the Preclinical animal house, University of Ibadan. They were kept under standard laboratory conditions, fed with rat' pellets and given water ad libitum. The animals were later divided into groups for the experimentation.

\section{Experimental Design}

The animals were divided into five groups. Group 1 animals which served as control were given $0.2 \mathrm{ml}$ of normal saline $(0.9 \% \mathrm{NaCl})$ daily for 30 days. Group II and III animals were given $100 \mathrm{mg}$ and $200 \mathrm{mg}$ garlic daily for 15 days. Group IV and V animals were given $100 \mathrm{mg}$ and $200 \mathrm{mg}$ garlic for 30 days. In all the groups the drug was administered via oral route.

Haematological and Biochemical Studies: On day 16 and 31 respectively, the rats were anaesthetized with ether after which heart puncture was carried out and the blood collected in EDTA bottles between 8 and 9 a.m. Packed cell volume, total and differential white blood cell counts, red blood cell count, and hemoglobin concentration of each sample was determined by using standard laboratory procedures. Serum electrolytes were determined by standard flame photometry. Chloride was assessed by the method of Schales and Schales (1941), and bicarbonate according to Toro and Ackermann (1975).

\section{RESULTS}

Hematological Study: Table 1 shows changes in red blood cell (RBC) counts, haemoglobin concentration $(\mathrm{Hb})$ and packed cell volume (PCV) following garlic treatment in rats. The mean values of RBC and PCV in rats given $200 \mathrm{mg} /$ day garlic for 30days did not significantly differ from the control $(P>0.05)$, however, there were significant increases in $\mathrm{RBC}$ and $\mathrm{PCV}$ for animals given low dose (100mg/day) of garlic for 30 days $(P<0.05)$.

Table 1

Red blood cell count, hemoglobin concentration and packed cell volume in garlic treated rats.

\begin{tabular}{|c|c|c|c|}
\hline $\begin{array}{l}\text { Group } \\
\text { treatment }\end{array}$ & 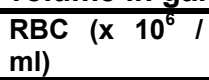 & $\mathrm{Hb}(\mathrm{g} / \mathrm{dl})$ & PCV (\%) \\
\hline $\begin{array}{l}\text { Control } \\
\text { (NS for 30d) }\end{array}$ & $6.00 \pm 0.10$ & $\begin{array}{l}15.00 \\
\pm 0.41\end{array}$ & $\begin{array}{l}43.8 \\
\pm 1.22\end{array}$ \\
\hline $\begin{array}{l}\text { Garlic (100mg } \\
\text { for 30d) }\end{array}$ & $7.78 \pm 0.52^{*}$ & $\begin{array}{l}16.33 \\
\pm 0.79\end{array}$ & $\begin{array}{l}49.7 \\
\pm 1.20^{*}\end{array}$ \\
\hline $\begin{array}{l}\text { Garlic }(200 \mathrm{mg} \\
\text { for 30d) }\end{array}$ & $6.02 \pm 0.10$ & $\begin{array}{l}14.25 \\
\pm 1.00\end{array}$ & $\begin{array}{l}42.7 \\
\pm 1.31\end{array}$ \\
\hline
\end{tabular}


Table 2: Total and differential white cell counts in short-term and long-term pre-treated rats with garlic.

\begin{tabular}{|c|c|c|c|c|c|}
\hline \multirow{3}{*}{$\begin{array}{ll}\text { White } & \text { cell } \\
\text { indices } & \end{array}$} & \multirow{3}{*}{$\begin{array}{ll}\text { Control } & \text { (NS) } \\
(12) & \end{array}$} & \multicolumn{4}{|c|}{ Garlic pretreatment $($ MEAN \pm SEM) } \\
\hline & & \multicolumn{2}{|c|}{ Short-term (15d) } & \multicolumn{2}{|c|}{ Long-term (30d) } \\
\hline & & $100 \mathrm{mg}$ & $200 \mathrm{mg}$ & $100 \mathrm{mg}$ & $200 \mathrm{mg}$ \\
\hline TWBC $\times 10^{3 / M L)}$ & $6.39 \pm 229$ & $\begin{array}{ll}6.600 & \pm \\
249.05 & \end{array}$ & $7.900 \pm 163.33^{*}$ & $6.483 \pm 523.18$ & $10,100 \pm 306.50$ \\
\hline Neutr (\%) & $57.2 \pm 3.14$ & $63.3 \pm 0.88$ & $67.8 \pm 1.14^{*}$ & $56.70 \pm 4.08$ & $61.0 \pm 2.34$ \\
\hline Lymph (\%) & $39.90 \pm 2.84$ & $38.5 \pm 0.89$ & $29.8 \pm 1.01^{*}$ & $39.0 \pm 4.12$ & $36.2 \pm 1.54$ \\
\hline Eosin (\%) & $1.42 \pm 0.64$ & $1.30 \pm 0.33$ & $0.83 \pm 0.40$ & $2.0 \pm 0.94$ & $1.33 \pm 0.71$ \\
\hline Mono (\%) & $1.50 \pm 0.40$ & $2.00 \pm 0.68$ & $1.50 \pm 0.34$ & $2.33 \pm 0.87$ & $2.33 \pm 0.82$ \\
\hline Baso (\%) & 0 & 0 & 0 & 0 & 0 \\
\hline
\end{tabular}

$P<0.05$ Compared with the control; Number of animals per group are in parenthesis; NS $=$ Normal saline pre-treated rats; TWBC + Total white cell count, Neutr+ Neutrophils; Lymph + Lymphocyte, Eosin+ Eosinphil Mono- monocyte, Baso= Basophil

Table 3: Shows the electrolyte levels in rats pre-treated with different doses of garlic

\begin{tabular}{llllll}
\hline & & \multicolumn{3}{c}{ Garlic pretreatment (Means \pm Sem } \\
\cline { 2 - 6 } & & \multicolumn{3}{c}{ Short-term (15d) } & Long-term (30d) \\
\hline Biochemical parameters & Control (NS) & $100 \mathrm{mg}$ & $200 \mathrm{mg}$ & $100 \mathrm{mg}$ & $200 \mathrm{mg}$ \\
\hline $\mathrm{Na}^{+}(\mathrm{mml} / 1)$ & 131.16 & 131.50 & 134.80 & 136.30 & 139.00 \\
& \pm 0.83 & \pm 0.85 & $\pm 1.01^{*}$ & $\pm 0.67^{*}$ & $\pm 0.73^{*}$ \\
\hline $\mathrm{K}^{+}(\mathrm{mmol} / 1)$ & 7.05 & 7.30 & 7.92 & 8.13 & 8.73 \\
& \pm 0.17 & \pm 0.17 & $\pm 0.10^{*}$ & $\pm 0.10^{*}$ & $\pm 0.05^{*}$ \\
\hline $\mathrm{Cl}(\mathrm{mmol} / 1)$ & 99.67 & 99.83 & 101.50 & 101.10 & 104.33 \\
& \pm 0.42 & \pm 0.48 & \pm 0.85 & \pm 0.83 & \pm 0.37 \\
\hline $\mathrm{HCO}(\mathrm{mmol} / 1)$ & 20.8 & 21.00 & 21.67 & 21.50 & 23.16 \\
& \pm 0.31 & \pm 0.37 & \pm 0.42 & \pm 0.43 & \pm 0.31 \\
\hline Urea $(\mathrm{mg} / \mathrm{d})$ & 30.67 & 37.33 & 39.16 & 38.083 & 39.80 \\
& \pm 0.88 & $\pm 0.88^{*}$ & $\pm 1.35^{*}$ & \pm 1.85 & $\pm 1.66^{*}$
\end{tabular}

$N=6 .{ }^{*} p<0.05$ compare with the control; $N S=$ normal saline pretreated rats.

Table 2 shows the white cell indices in garlic pre-treated rats for 15 days and 30days. The neutrophil and lymphocyte levels and the TWBC of the rats given 200mg garlic per day for fifteen days duration were statistically higher than the control animals $(P<0.05)$. There was however no significant changes in differential leukocyte indices post 30days garlic treatment except for the significant increase in TWBC following treatment with garlic for 30 days $(P<0.05)$. It should be noted that in all group treated with garlic, there were high neutrophil/lymphocyte ratio.

Biochemical Parameters: The results obtained on the effect of garlic pre-treatment on biochemical indices are shown in table 3 . After ' 15 days pre-treatment of the animals with $100 \mathrm{mg}$ day garlic, the serum electrolyte levels were not affected. However, the serum levels of $\mathrm{Na}^{+}$and $\mathrm{K}^{+}$progressively and significantly increased with both doses and long-term (30d) of treatment when compared with the control $(P<0.05)$. There were significant increases in serum urea with 100 and 200mg per day administration of garlic after 15 days and 30 days post treatment $(\mathrm{P}<0.05)$.

\section{DISCUSSION}

Preliminary investigation on acute toxicity study in mice showed that the extract was not toxic to mice at the tested doses.
The study showed that rats given higher doses of garlic had a preponderance of neutrophil over lymphocyte in respective of duration. Also, a higher dose of $200 \mathrm{mg} /$ day garlic given for a longer period was observed to cause a significant increase in total white blood cell (TWBC). These data therefore support the earlier reports by Sumiyoshi (1997) that garlic extracts stimulate immune functions. This observation may partly explain the role of garlic in activating the natural killer cells, the function of T-lymphocytes and the level of interleukin - 2 (Tang et al, 1997).

Table 3 shows significant increase in the serum levels of urea during short - and long - term treatment with garlic. The serum levels of sodium and potassium also increased significantly with higher doses of garlic (Table 3). This finding is suggestive of a mild hyperkalaemic and hypernatriemic effects. The drug in addition to its other actions may favour an improvement in renal function by increasing sodium and potassium reabsorption. The relieve of hypertension by allicin component of garlic may partly be explained by its secondary effect on possible increase in renal blood flow which enhances renal reabsorption of basic electrolytes like sodium and potassium.

\section{ACKNOWLEDGEMENT}

The author is grateful to Messrs B.A. Meraiyebu and H.O. Oyeyinka for their technical assistance. 


\section{REFERENCES}

Alan, D.K; Nossaman, B.D; Ibrahim, I.N, Feng, C.J Mc Namara, D.B; Agrawal, K.C and P.J Kadpwitz (1995): Analysis of responses of allicin, a compound from garlic, in the pulmonary vascular bed of the cat and in the rat. Euro. J. Pharmacology 276,21-26

Apitz-Castro, R; S. Cabrera: M.R. Cruz: E. Ledezma and M.K. Jain (1983). Effects of garlic extracts and of these pure components isolated from it on human platelet aggregation, arachidonate metabolism, release reaction and platelet ultrastructure. Thromb Res. 32. 155.

Gill L.S. (1992). Ethnomedical uses of plants in Nigeria. Uniben press.

McMahon, F.G and R.Vargas (1993). Can garlic lower blood pressure? A pilot study. Pharmacotheraphy 13(4), 406.
Sang, G.K; S.Y.Nam; H.C. Chung; S.Y. Hongand K.H Jung (1995). Enhanced effectiveness of dimethyl-4,41 ${ }^{1}$-dimethoxy $5,6,5^{1}, 6^{1}$,-dimethylene dioxybiphenyl $-2,2^{1}$ - dicarboxylate in combination with garlic oil against experimental hepatic injury in rats and mice. J. Pharm. Pharmacol 47, 678-682.

Schales, P and Schales, S.S (1941). A simple and accurate method for the determination of chloride in biological fluids. J. Biol Chem 140, $879-884$.

Sumiyoshi: H. (1997) New pharmacological activities of garlic and its constituents (Review). Folia Pharmacological Japonica 110 Suppl 1, $93-97$.

Tang, Z; Z. Sheng, S. Liu: X. Jian; K. Suin and Yan. M (1997). Preventing function of garlic on experimental oral precancer and its effect on natural killer cells. Bulletin of Human Medical University 22, $31246-8$.

Toro, G; and Ackermann P (1975). Practical clinic al chemistry, $1^{\text {st }}$ ed. Little Brown and Company. Boston. 